\title{
Coming up for Air: On Reading in a Global Pandemic
}

Aparna Mishra Tarc York University 


\begin{abstract}
:
The thought of breath grips the world as climate change, racial injustice and a global pandemic converge to suck oxygen, the lifeforce, out of the earth. The visibility of breath, its critical significance to existence, I argue, is made evident by poets. To speak of breath is to lodge ourselves between birth and death and requires sustained, meditative, attentive study to an everyday yet taken for granted practice. Like breathing, reading is also a practice that many took for granted until the pandemic. This keynote address engages the affective and/or poetic dimensions of reading left out of theories of literacy that render it instrumental and divorced from the life of the reader (Freire, 1978). I suggest that scholars of literacy, in every language, begin to engage a poetics of literacy as attending to the existential significance of language in carrying our personhood and lives. I also argue that our diminishing capacities to read imaginatively and creatively have led to the rise of populist ideologies that infect public discourse and an increasingly anti-intellectual and depressed social sphere. Despite this decline in the practice and teaching of reading, it is reported that more than any other activity, reading sustained the lives of individuals and communities' during a global pandemic. Teachers and scholars might take advantage of the renewed interested in reading to redeliver poetry and literary language to the public sphere to teach affective reading. Poetry harkens back to ancient practices of reading inherent in all traditions of reading. It enacts a pedagogy of breath, I argue, one that observes its significance in our capacity to exist through the exchange of air in words, an exchange of vital textual meanings we have taken for granted as we continue to infect our social and political world and earth with social hatred, toxins, and death. In this address, I engage fragments of poetry by poets of our time ( $20^{\text {th }}$ century onward) that teaches us to breathe and relearn the divine and primal stance that reading poetry attends to and demands. More than any other form, "poetry," Ada Limon (2011) claims, "has breath built into it" (para. 8). As such, reading poetry helps us to breathe when the world bears down and makes it hard for us to come up for air.
\end{abstract}

Keywords: affect; breath; poetry; pedagogy; subject formation; coronavirus pandemic; literacy; reading 


\section{S'approcher pour l'air : au sujet de la lecture en période de pandémie}

\section{Résumé :}

L'idée de la respiration s'empare du monde alors que le changement climatique, l'injustice raciale et une pandémie mondiale convergent à aspirer l'oxygène, la force vitale, de la terre. Pour ma part, la visibilité du souffle, son importance primordiale pour l'existence, est mise en évidence par des poètes. Parler de respiration, renvoie à se placer entre la naissance et la mort; ce qui exige une étude attentive, soutenue et méditative d'une pratique quotidienne tenue pour acquise. Comme la respiration, la lecture est également une pratique que de nombreuses personnes tenaient pour acquise avant l'avènement de la pandémie. Ce discours d'ouverture mobilise les dimensions affectives et/ou poétiques de la lecture qui ont été écartées des théories de l'alphabétisation qui l'instrumentalisent et la séparent de la vie du lecteur (Freire, 1978). Je suggère que les chercheurs en alphabétisation, dans toutes les langues, commencent par s'engager dans une poésie de l'alphabétisation qui tienne compte de la signification existentielle du langage dans le transport de notre personnalité et de nos vies. Je suggère également que la diminution de nos capacités à lire de manière imaginative et créative a conduit à la montée des idéologies populistes qui infectent le discours public et une sphère sociale de plus en plus antiintellectuelle et déprimée. Malgré ce déclin de la pratique et l'enseignement de la lecture, on rapporte que, la lecture, plus que toute autre activité a permis aux individus et aux communautés de tenir le coup pendant la pandémie mondiale. Les enseignants et chercheurs gagneraient à profiter de l'intérêt renouvelé pour la lecture afin de raviver l'affection pour la poésie et le langage littéraire auprès du public. La poésie renvoie aux pratiques anciennes de la lecture inhérentes à toutes les traditions littéraires. Elle met en œuvre une pédagogie du souffle, je crois, qui observe sa signification dans notre capacité à exister par l'échange d'air dans les mots, un échange de significations textuelles vitales que nous avons pris pour acquis alors que nous continuons de dominer notre monde politique et social, ainsi que la terre, de haine sociale, de toxine et de la mort. Dans ce discours, j'aborde des fragments de poésie par des poètes de notre temps (à partir du 20siècle dernier) qui nous enseignent à respirer et à réapprendre la position divine et primale que la lecture de la poésie attend et exige. «La poésie, plus que toute autre forme littéraire, a du souffle en elle » affirme Adam Limon (2011, para. 8; traduction libre). En tant que telle, la lecture de la poésie nous aide à respirer lorsque le monde s'effondre et qu'il nous est difficile de reprendre notre souffle.

Mots clés : affect; souffle; poésie; pédagogie; formation du sujet; pandémie du coronavirus; 
alphabétisation; lecture

\author{
Perhaps love is \\ emptiness \& fullness \\ silence $\&$ hearing \\ the still pause between \\ the heart's systole $\&$ disastole, \\ spirit-filled breath \\ in the grammar \\ of our sentences.
}

(Sameshima \& Leggo, 2013)

\begin{abstract}
parna Mishra Tarc is Associate Professor and Graduate Program Director at the Faculty of Education, York University. This paper was originally given as a keynote address at the Graduate Student Conference at the Faculty of Education, Lakehead University, Orillia and Thunder Bay, Ontario, on Tuesday, March 25, 2021. It has since been recorded and is available at the audio-visual channel of JCACS/RACEC, JCACS Curriculum Without Borders.
\end{abstract}




\section{References}

Banerjee, A. K. (2020, December 27). Tagore and pandemics. The Statesman. https://www.the statesman.com/opinion/tagore-and-pandemics-1502942965.html

Brande, D. (2021). What we saw. What we made. When we emerge. Kitty Memorial Lecture, York University.

Brown, J. (2019). The tradition. Copper Canyon Press.

Brown, J. (2020, June 15). Say thank you say I'm sorry. New York Times. https://www.nytimes.com/ 2020/06/15/books/review/jericho-brown-say-thank-you-say-im-sorry-poem-coronavirus.html

Coetzee, J. M. (2013, November 29). Take a stand on academic freedom. University World News. https://www.universityworldnews.com/post.php?story=20131126223127382

Coles, R. (1977, July 31). James Baldwin back home. New York Times. https://archive.nytimes.com/ www.nytimes.com/books/98/03/29/specials/baldwin-home.html

Derrida, J. (1985). Letter to a Japanese friend. In R. Bernasconi \& D. Wood (Eds.) Derrida and Différance (pp. 71-82). Parousia Press. (Originally written in 1983)

Du Bois, W. E. B. (1906). The health and physique of the Negro American: Report of a social study made under the direction of Atlanta university, together with the proceedings of the Eleventh Conference for the Study of the Negro Problems, held at Atlanta University, on May the 29th, 1906. https://openlibrary.org/books/OL6989824M/The_health_and_physique_of_the_Negro_ American.

Du Bois, W. E. B. (1920). Darkwater: Voices from within the veil. Harcourt Brace.

Fitzpatrick, C. (2020, April 27). Only the poets will be able to make sense of this. The Irish Times. https://www.irishtimes.com/opinion/only-the-poets-will-be-able-to-make-any-sense-of-this1.4238341

Freire, P. (1983). The importance of the act of reading. Journal of Education, 165(1), 5-11.

Freud, S. (2010). The interpretation of dreams. The complete and definitive text (J. Strachey, Trans.) Basic Books. (Originally published in 1915)

Greene, M. (1982). Education and disarmament. Teachers College Record, 84(1): 128-136. https://maxinegreene.org/uploads/library/education_disarmament.pdf

Jenkins, E. R. (2005). The 1919 Influenza Blues [Audio recording]. Smithsonian Folkways Recordings. https://folkways.si.edu/essie-jenkins/the-1919-influenza-blues/african-americanblues/music/track/smithsonian (Originally produced ca. 1930)

Joudy, F. (2021). How one doctor's love for poetry helps him communicate with patients better. PBS NewsHour. https://www.pbs.org/newshour/show/how-one-doctors-love-for-poetry-helpshim-communicate-with-patients-better

Kaminsky, I. (2019). Deaf republic: Poems. Greywolf Press. 
Kristeva, J. (2018, November). It's just not my life-Julia Kristeva responds (P. Baudoin, Trans., O. Bourchara, Interviewer). BLARB Blogs/Los Angeles Review Of Books. https://blog.lareviewof books.org/essays/just-life-julia-kristeva-responds/ (Originally published July 2018 in Vanity Fair France)

Limon, A. (2011, April 11). Why poetry helps. Guernica. https://www.guernicamag.com/ada_limn _why_poetry_helps/

Limon, A. (2015). Adaptation. Bright dead things: Poems. Milkweed.

Mishra Tarc, A. (2015). Literacy of the other: Re-narrating Humanity. State University of New York Press.

Morrison, T. (2020). The Source of self-regard: Selected essays, speeches, and mediations. Penguin.

Reese, G. (2020, April 24). Virus now, virus then. Our Weekly. http://ourweekly.com/news/ 2020/apr/24/virus-now-virus-then/

Rose, J. (2020, November 19). To die one's own death. London Review of Books. https://www.lrb. co.uk/the-paper/v42/n22/jacqueline-rose/to-die-one-s-own-death

Rosenblatt, L. (1986). The aesthetic transaction. Journal of Aesthetic Education, 20(4), 122-128. https://doi.org/10.2307/3332615

Roy, A. (2003). War talk. Sound End Press.

Sameshima, P., \& Leggo, C. (2013). How do you spell love? Curricular conversations. Creative approaches to research, 6(1): 89-109.

Stillwaggon, J. (2016). The indirection of influence: Poetics and pedagogy in Aristotle and Plato. Journal of Aesthetic Education, 50(2), 8-25. https://doi.org/10.5406/jaesteduc.50.2.0008

Waiser, B. (2020, October 4). A case for commemorating Chief Big Bear: An early advocate for Indigenous rights. CBC. https://www.cbc.ca/news/canada/saskatoon/chief-big-bearsaskatchewan-1.5748860

Zagajewski, A. (2002). Without end: New and selected poems. Farrar, Straus \& Giroux. 